УДК 659.113 .254

\title{
СУЧАСНІ ТЕНДЕНЦІЇ РОЗВИТКУ РЕКЛАМНОГО РИНКУ УКРАЇНИ
}

\section{CURRENT TRENDS IN THE ADVERTISING MARKET OF UKRAINE DEVEOPMENT}

\author{
Григорова Зоя Валентинівна \\ кандидат економічних наук, доцент, \\ Національний технічний університет України \\ «Київський політехнічний інститут імені Ігоря Сікорського» \\ ORCID: https://orcid.org/0000-0003-4547-9812
}

\author{
Grygorova Zoia \\ National Technical University of Ukraine \\ "Igor Sikorsky Kyiv Polytechnic Institute"
}

\begin{abstract}
Реклама є невід'ємною частиною маркетингових комунікацій брендів, основним джерелом інформування цільової аудиторії про товари та послуги. В статті розглянуто сучасний стан рекламного ринку України, досліджено його окремі сегменти та окреслено основні тенденції розвитку, Розглянуто динаміку ринку реклами за 2016-2020 роки, проаналізовано його розвиток під впливом соціально-економічної кризи, спричиненою пандемію COVID-19, визначено сегменти, що зазнали найбільшого впливу кризи. Встановлено, що найбільш вагомими каналами рекламних комунікацій є реклама на телебаченні та інтернет реклама, частка якої в структурі рекламного ринку протягом останніх років суттєво збільшується. Окреслені зміни, що відбуваються в окремих сегментах та дотичних галузях та визначено основні тенденції розвитку рекламного ринку України.

Ключові слова: реклама, ринок реклами, рекламна діяльність, рекламодавець, криза.
\end{abstract}

Реклама является неотъемлемой частью маркетинговых коммуникаций брендов, основным источником инорормирования целевой аудитории о товарах и услугах. В статье рассмотрено современное состояние рекламного рынка Украины, исследованы его отдельные сегменты и обозначены основные тенденции развития. Рассмотрена динамика рынка рекламы за 2016-2020 годы, проанализировано его развитие под влиянием социально-экономического кризиса, вызванного пандемией COVID-19, определены сегменты, подвергшиеся наибольшему влиянию кризиса. Установлено, что наиболее значимыми каналами рекламных коммуникаций является реклама на телевидении и интернет реклама, доля которой в структуре рекламного рынка в последние годы существенно увеличивается. Обозначены изменения, которые происходят в отдельных сегментах и определены основные тенденции развития рекламного рынка Украины.

Ключевые слова: реклама, рынок рекламы, рекламная деятельность, рекламодатель, кризис.

Advertising is an integral part of brand marketing communications, the main informing source for target audience about goods and services. The article considers the advertising market of Ukraine current state, examines its main segments and outlines the main trends, considers the dynamics of the advertising market for 2016-2020, analyzes its development under the influence of socio-economic crisis caused by the COVID-19 pandemic, identifies segments affected the greatest impact of the crisis. The functioning of the advertising market takes place in the changing conditions of the external environment. The development of the global and domestic advertising market in 2020 took place in conditions of economic, social and political instability. During 2020 the largest reduction occurred in the segment of outdoor advertising, due to restrictions on the operation of public transport and restorans and entertainment activities. The reduction also occurred in the advertising segment in the print media, as capacity for their production and distribution was stopped. Radio advertising has not changed, and television advertising has grown. The highest growth rates in the segment of Internet advertising, which is a global trend. The biggest decline in advertiser activity occurred in the second quarter of 2020, when advertisers canceled or postponed advertising campaigns. But in the third quarter, advertising activity returned to pre-crisis levels as businesses began to adapt to changes and embed new business models. The cessation of advertising campaigns disrupts the established communication with consumers, for the restoration of which then need to spend extra money. In this research was established that the most important channels of advertising communications in the market are advertising on television and Internet 
advertising, the share of which in the structure of the advertising market in recent years has increased significantly. The article also outlines the changes taking place in main advertising market segments and related industries and describes the main trends in the advertising market of Ukraine.

Keywords: advertising, advertising market, advertising activity, advertiser, crisis.

Постановка проблеми. В умовах значної конкуренції на ринку товарів і послуг загострилась боротьба за залучення споживачів. Одним з методів привернути увагу і викликати інтерес цільової аудиторії є реклама. Розвиток ринкової економіки та трансформаційні процеси, що відбуваються в економіці країни, сприяли виокремленню і оформленню реклами як окремої потужної галузі 3 налагодженими економічними, правовими, культурними і соціальними зв'язками. Питома вага рекламної діяльності і дослідження кон'юнктури ринку у 2020 році за даними Державного комітету статистики України становила 4,2\% від загального обсягу реалізованих послуг.

В наш час реклама $€$ невід'ємною частиною системи маркетингових комунікацій бренду. Від фрінансового положення бізнесу залежить величина рекламних бюджетів, а, отже, і стан та перспективи подальшого розвитку рекламної галузі. Рекламна галузь значною мірою залежить від економічної, політичної, соціальної ситуації в країні. Економічні зміни, пов'язані з епідемією COVID-19, нестабільна політична ситуація в країні зумовлюють необхідність досліджень їх впливу на стан та перспективи розвитку рекламної галузі України.

Аналіз останніх досліджень і публікацій. Теоретичні і практичні аспекти реклами висвітлені у працях багатьох вітчизняних та зарубіжних авторів, зокрема: Д. Огівлі, Дж. О'Тула, Л. Барнетта, С. Моріарті, Ф. Джефкінса, Д. Аакера, Дж. Мейєрса, Т. Лук'янець, Г. Почепцова, $€$. Ромата та ін. Разом з тим, слід зазначити, що діяльність рекламної галузі відбувається в умовах мінливого зовнішнього середовища. Останнім часом відбулися значні зміни в соціально-економічному і політичному житті країни, вплив яких на розвиток вітчизняного рекламного ринку потребує подальшого дослідження.

Формулювання цілей статті (постановка завдання). Основною метою роботи є дослідження стану розвитку рекламного ринку України; вивчення змін, викликаних процесами, що відбуваються в соціально-економічному і політичному житті країни; визначення тенденцій його розвитку.

Виклад основного матеріалу дослідження. Розвиток світового і вітчизняного рекламного ринку в 2020 році відбувався в умовах економічної, соціальної і політичної нестабільності. Пандемія короновірусної інфрекції призвела до виникнення світової економічної кризи, кардинальних змін в економічному і соціальному житті країн та їх населення. За докарантинними прогнозами компанії eMarketer приріст витрат на рекламу в світі у 2020 році мав становити 7\%, але через пандемію фрактично вони скоротились на 4,5\% у порівнянні з 2019 роком [1]. Незважаючи на це в 2020 році обсяг світового ринку реклами становив 647 млрд. дол. [2].

Крім загального спаду ділової активності, спричиненого пандемією, та скорочення маркетингових бюджетів брендів, розвиток рекламного ринку України в 2020 році відбувався під впливом кодування супутникових сигналів телевізійних каналів, що мало зменшити доступний інвентар для рекламодавців, переформатування і появи нових сейлхаузів 3 продажу телевізійної реклами, проведення місцевих виборів, коливання курсу національної валюти.

На українському рекламному ринку виділяють наступні основні сегменти: телевізійна реклама, реклама в пресі, радіо реклама, зовнішня реклама, реклама в кінотеатрах, та інтернет реклама. Найбільшим сегментом рекламного ринку є інтернет реклама, питома вага якої постійно збільшується, і у 2020 році складає 53\%. На другому місці йде телевізійна реклама, частка якої у 2020 році становить $32,6 \%$ (рис. 1).

Перерозподіл рекламного ринку і зростання частки інтернет реклами $€$ загальносвітовою тенденцією. Менш ніж за п'ять років витрати на інтернет рекламу в світі майже подвоїлися і на цисррові канали припадає більше половини загальних витрат на рекламу [4]. Зміни у мадіаландшасрті і поведінці цільових аудиторій змушують рекламодавців постійно адаптувати свої медіа стратегії. Масовий перехід цільових аудиторій в інтернет середовище викликав перетікання рекламних бюджетів від традиційних каналів поширення реклами у цифрові, що потягло за собою виникнення кризи в друкованих ЗМІ, адже більшість з них працювали на основі «рекламної» бізнес моделі.

Після кризи в 2014 році протягом останніх років рекламний ринок України характеризувався стабільним ростом (рис. 2). 


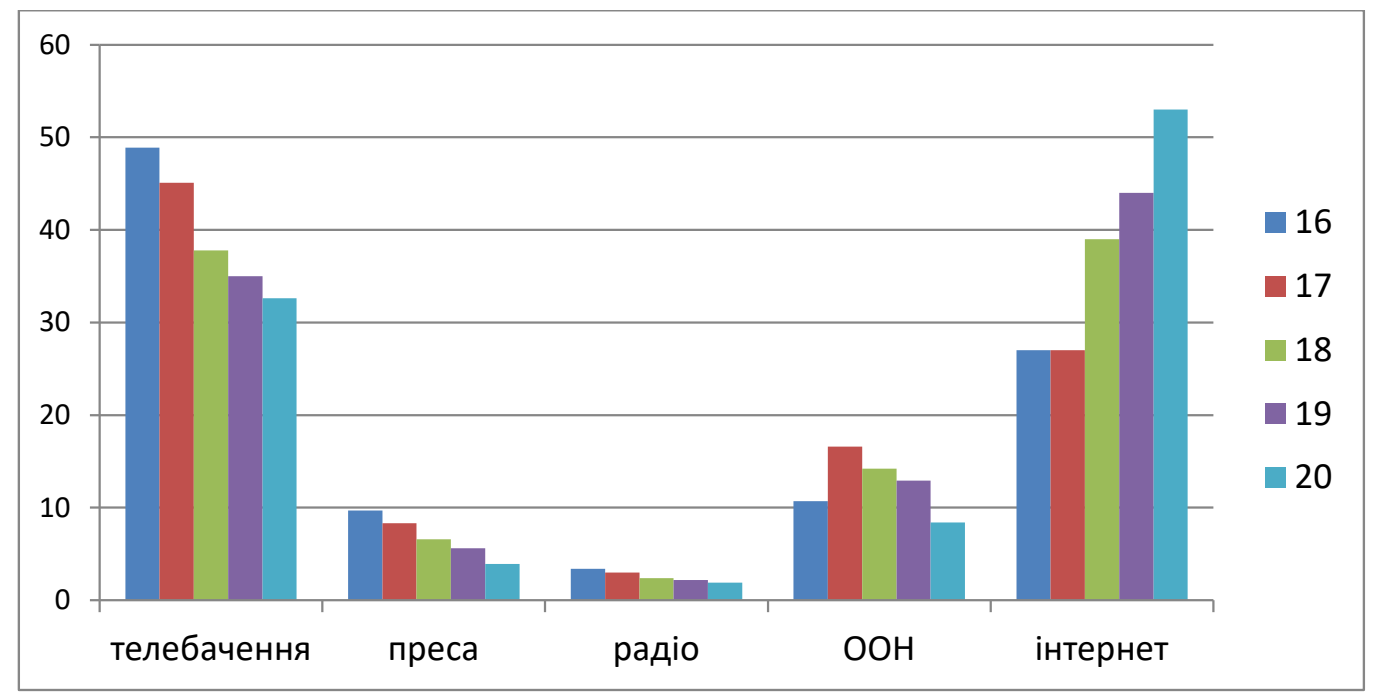

Рис. 1. Структурно-динамічний аналіз рекламного ринку України 2016-2020 рр. Джерело: розроблено автором за даними сайту Всеукраїнської Рекламної коаліції [3]

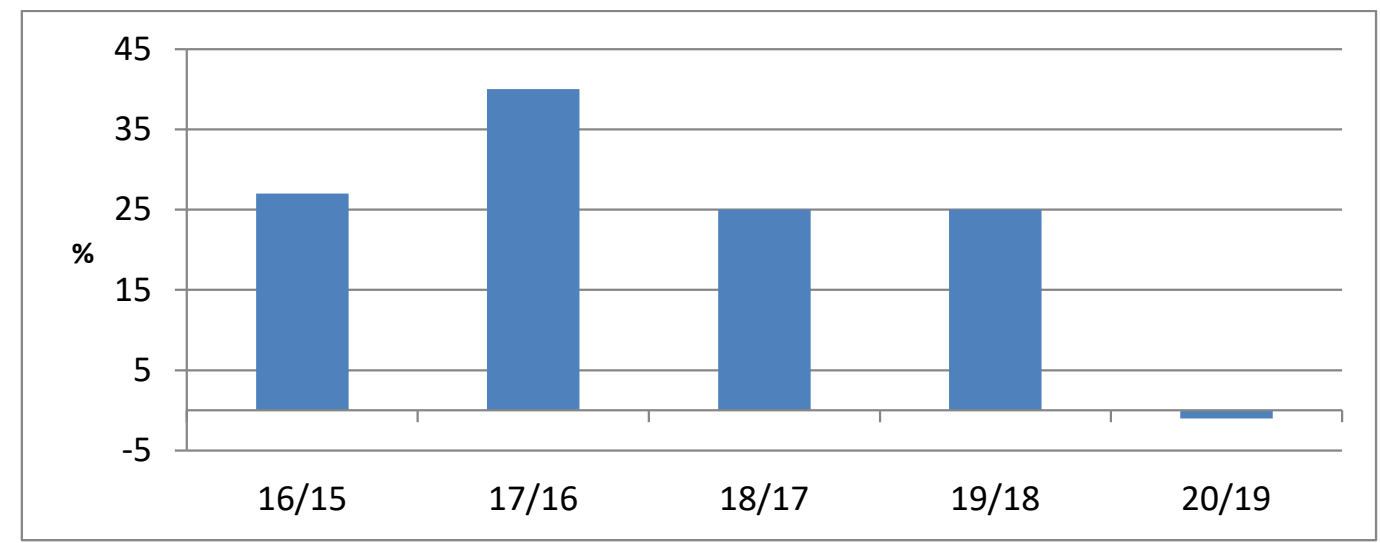

Рис. 2. Темпи приросту обсягів рекламного ринку України за 2016-2020рр., \% Джерело: розроблено автором за даними сайту Всеукраїнської Рекламної коаліції [3]

Найвищі темпи зростання спостерігалися у секторі Digital (Internet) реклами, що пов'язано 3 подальшою діджиталізацією медіа та їх мультиплаторорменістю (рис. 3).

На фроні кризи, спричиненої пандемією, найбільшого падіння у 2020 році зазнали реклама в кінотеатрах, транспорті, внутрішня і зовнішня реклама та реклама в пресі.

Тимчасові зупинки та введення обмежень на перевезення у громадському транспорті привели до скорочення рекламних бюджетів брендів на транспортну рекламу. Закриття i обмеження відвідуваності кінотеатрів і закладів харчування (ресторанів, касре), офрлайн торговельних закладів, розважальних центрів та заходів суттєво знизили попит на внутрішню рекламу. Зниження інтенсивності пересування населення на фоні пандемії та розвиток геолокаційних сервісів і онлайн карт знизили попит у сегменті зовнішньої реклами. Також зміна правил розміщення пристроїв зовнішньої реклами в містах привела до скорочення їх кількості.

Єдиним сектором ООН реклами, який активно розвивався навіть в умовах кризи був Digital OOH. На даному сегменті спостерігалось зростання як рекламного інвентарю так і розміщення рекламодавців на ньому.

Суттєвого впливу карантинні обмеження мали і на рекламу у друкованих 3МІ. Через введені обмежувальні заходи відбулося тимчасове закриття виробничих потужностей з їх виготовлення та мереж дистрибуції видань. До того ж значну частину доходів газет і журналів становлять рекламні надходження і через призупинення або зменшення обсягів рекламних кампаній в пресі від початку карантину припинили вихід близько двох сотень газет і журналів, 


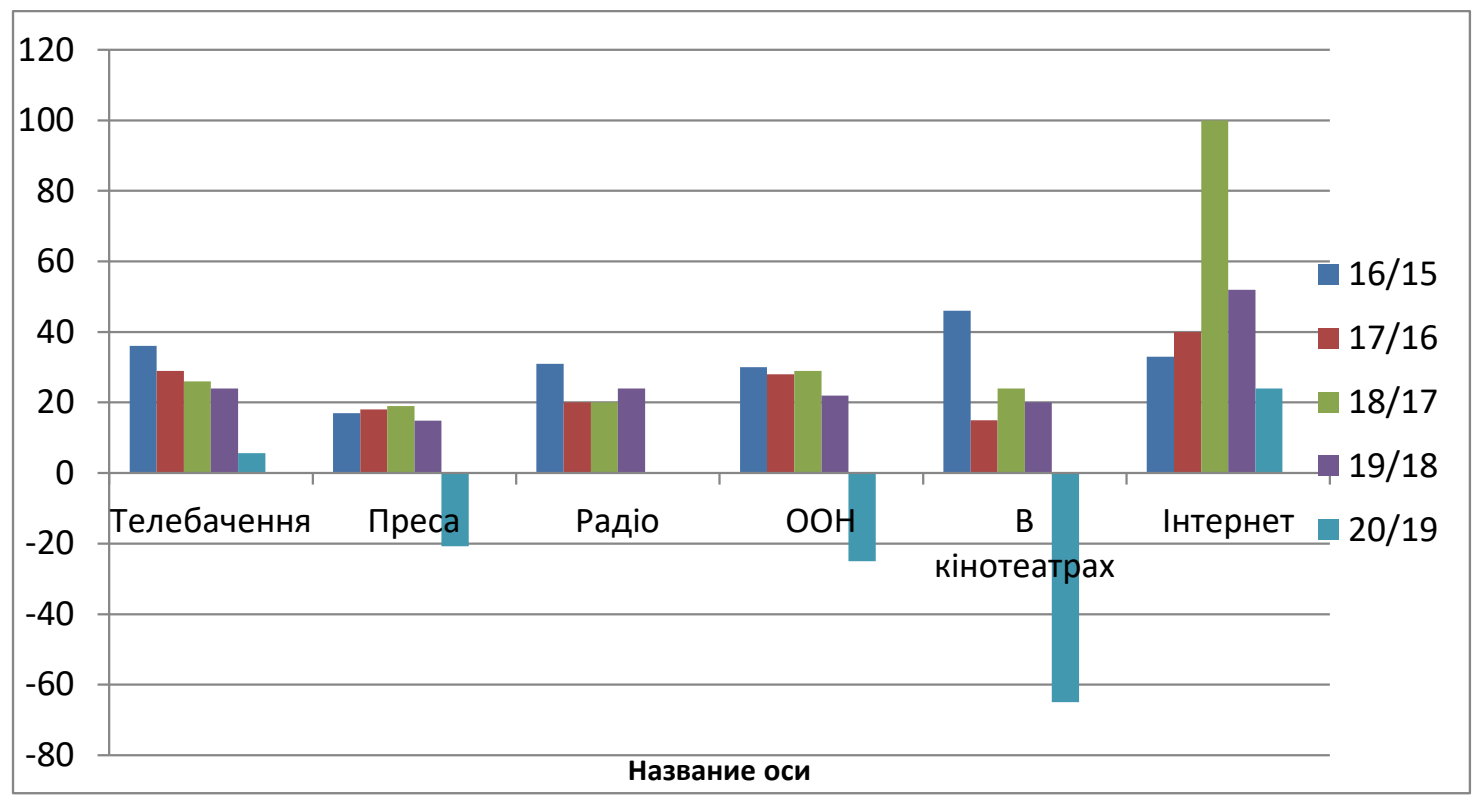

Рис. 3. Темпи приросту по окремих видах реклами за 2016-2020 рр., \%

Джерело: розроблено автором за даними сайту Всеукраїнської Рекламної коаліції [3]

інші значно знизили періодичність випуску та обсяги видань [5] За даними Книжкової палати у 2020 році (дані за 9 місяців) обсяги скорочення загального тиражу друкованих періодичних та продовжуваних видань становили 60\%, а газет 40\% [6]. Найбільшого впливу зазнали загальнонаціональні газети і журнали, оскільки вони найбільш залежні від налагодженої роботи системи дистрибуції та рекламодавців.

Зменшення надходжень всеукраїнських видань у регіони дозволило зберегти, а в окремих випадках і підвищити, випуск регіональних газет і журналів, оскільки вони, крім всього, менш залежні від роботи системи загальнонаціональної логістики і змогли знайти нові канали дистрибуції (наприклад у закладах роздрібної торгівлі, які не були закриті під час локдауну).

Через кризу, яку викликала пандемія, в світі і в Україні в сегменті періодичних видань прискорився перехід на електронні версії газет і журналів і відмова від виготовлення їх паперової версії. Це значно знижує вартість видань, спрощує процес їх дистрибуції. Видання почали пошук інших моделей фрінансування, які б зменшили їх залежність від надходження рекламних коштів - краудфрандинг, платний доступ (пейвол), збір донейтів, клуби читачів тощо.

Обсяги рекламних бюджетів на радіо у 2020 році не зазнали змін. В той час як окремі рекламодавці суттєво зменшили бюджети, інші компанії вирішили збільшити свою присутність на рекламному ринку скористав- шись зниженням цін на розміщення реклами і завантаженості ефріру. Також з'явилися нові рекламодавці, основну частину яких складають онлайн сервіси. На радіо зменшилась присутність рекламодавців в категоріях «Розваги», «Нерухомість» та ін., а категорії «Лікарські засоби», «Продовольчі товари» та «Медицина» показали ріст. Але зміни у найвагоміших рекламних категоріях на радіо почались ще у 2019 році, коли зменшилась частка реклами алкогольних напоїв, водночас більше рекламного часу стали викупати фрармацевтичні компанії, фрінансовий сектор та FMCG (fast moving consumer goods - продукти, товари гігієнічного призначення, побутова хімія тощо) [7].

Так само як і в друкованих 3MІ в прослуховуванні радіо намітилася тенденція до зростання онлайн споживання радіо.

У 2020 році ринок телевізійної реклами показав ріст на 5,6\%. 3 початку пандемії суттєво зріс час телеперегляду, популярність послуг онлайн кінотеатрів. Основну частину рекламних бюджетів на телебаченні традиційно фрормують FMCG, лікарські засоби, зв'язок та торгівля (у зв'язку із тимчасовим закриттям магазинів деякі ритейлери переключилися на рекламу своїх інтернет майданчиків). Під час локдауну частина компаній призупинила проведення рекламних акцій на телебаченні. До їх числа відносяться товари, які не є товарами першої необхідності, або такі, що не можна купити онлайн, послуги, події, які тимчасово були недоступні або, які 
успішно продавалися і без реклами (виробники продуктів харчування, засобів гігієни та побутової хімії). Найбільшого скорочення у другому кварталі зазнали такі категорії як «Фінанси», «Розваги», «Туризм», діяльність яких була суттєво обмежена під час локдауну. Інша частина брендів збільшила свою рекламну присутність, скориставшись пільговими цінами та умовами на розміщення реклами, що були встановлені сейлз-хаузами для нівеліювання негативного впливу пандемії. Починаючи 3 третього кварталу 2020 року заповнюваність реклами на телебаченні повернулась на докризовий рівень.

У найбільш скрутній ситуації на телевізійному ринку опинилися регіональні телеканали, клієнти яких згорнули рекламні кампанії або перевели їх у диджитал, а нові рекламодавці на їх місце не прийшли. За словами представників регіональних мовників, на регіональному ТБ залишилося лише 10-15\% від бюджетів [8].

У ніч на 29 січня 2020 року 22 найбільш рейтингових телеканали чотирьох провідних медіагруп закодували свій супутниковий сигнал. Протягом декількох місяців були закодовані сигнали ще ряду каналів (канали Film. ua Group, Bolt, Music Box та ін.). Але з 2 млн. користувачів у безкоштовного супутникового мовлення лише близько 30\% перейшли до платного сегменту. Процес переходу на платне телебачення також стримується домовленостями медіагруп 3 керівництвом країни щодо трансляції на супутнику некодованих міжнародних версій каналів. Однак, кодування сигналу та падіння охоплення, за оцінкою експертів, на продажі реклами не вплинуло.

В 2021 році змінилась конорігурація продаж реклами провідних медіа груп, через які реалізується 97\% телевізійної реклами. Внаслідок розпаду так званого «Альянсу» трьох медіагруп StarLightMedia, «Медіа Група Україна» та Inter Media Group та його переорорматування відбулося утворення нових коаліцій StarLightMedia 3 «1+1 медіа» та «Медіа Групи Україна» 3 Inter Media Group. Рекламодавці для розміщення реклами на телебаченні повинні обирати між ними і зміна конорігурації, на думку експертів, надасть їм більшу свободу вибору.

Найбільш динамічно на ринку реклами в Україні розвивається сегмент інтернет реклами, який у 2020 році попри кризу показав ріст на 24\%. Таке зростання пов'язане 3 зміною медіа споживання (охоплення та час проведений онлайн у з року в рік зростає і за цільовою аудиторією на цифррові майданчики переходять і рекламодавці) та можливістю проведення таргетованої рекламної кампанії і іiї регулювання, що у випадку з традиційними носіями зробити складно. До того ж зростання цін у цьому сегментів відбувається більш повільно у порівнянні з ООН та телебаченням. Найбільшими рекламодавцями в інтернет $€$ компанії е-commerce, беттінгу та мобільні оператори.

Висновки. Існуючі через пандемію обмеження змінили усталені звички і сфрормували нові. Соціально-економічна криза, що виникла через COVID-19, мала негативний вплив на більшість сегментів рекламного ринку та дотичних галузей. Через бізнес втрати рекламодавці скоротили маркетингові витрати і здійснили перерозподіл рекламних бюджетів. Зміна умов господарювання змусила організації адаптуватися до них і викликала необхідність зміни бізнес моделей та призвела до скорочення обсягів діяльності або припинення існування компаній, що цілком залежні від рекламних надходжень.

Найбільший спад рекламної активності спостерігався у другому кварталі 2020 року, коли значна частка рекламодавців відклала або скасувала свої проекти, однак на початку червня більшість 3 них відновили свої активності. Відмова від рекламування товарів призводить до розірвання зв'язків з цільовою аудиторією, a їх відновлення потребуватиме додаткових витрат. До того ж ситуацією, що склалася скористалися інші компанії, які навпаки підсилили свою присутність у рекламному просторі, адже під час кризи дуже часто формується нова лояльність споживачів до брендів.

Найбільшими каналами рекламних комунікацій на вітчизняному телевізійному ринку $є$ інтернет реклама, яка протягом останніх років активно розвивається та нарощує свої обсяги, та реклама на телебаченні. Перетікання цільової аудиторії на цифрові майданчики, можливість таргетингу та гнучкість інтернет реклами сприяло перерозподілу рекламних бюджетів на користь digital. Реклама в друкованих 3MІ поступово втрачає свої позиції, що є наслідком змін у медіаспоживанні та проблем 3 дистрибуцією накладів, переходу на електронні версії газет і журналів, появою порталів і сайтів новин. Іншою помітною тенденцією на ринку реклами в Україні $\epsilon$ розвиток Digital $\mathrm{OOH}$.

Отже, одним з найбільш важливих чинників розвитку рекламного ринку є подолання кризових явищ, пов'язаних з пандемією COVID19, та стабілізація соціально-економічної ситуації в Україні. 


\section{СПИСОК ВИКОРИСТАНИХ ДЖЕРЕЛ:}

1. How Total Media Ad Spend Will Shake Out Around the World. URL: https://www.emarketer.com/content/howtotal-media-ad-spend-shaking-around-world?fbclid=IwAR1NOqbD8LOzFT-iuJLaHbgCpb_HBZunt9MsHZTKLPV3Fx3cfUPBD1_rto (дата звернення: 26.02.2021).

2. Global Advertising Market: Industry Trends, Share, Size, Growth, Opportunity and Forecast 2021-2026. URL: https://www.imarcgroup.com/global-advertising-market (дата звернення: 26.02.2021).

3. Офріційний сайт Всеукраїнської рекламної коаліції. URL: https://vrk.org.ua/ad-market/ (дата звернення: 26.02.2021).

4. Visualizing the Evolution of Global Advertising Spend (1980-2020). URL: https://www.visualcapitalist.com/ evolution-global-advertising-spend-1980-2020/ (дата звернення: 28.02.2021).

5. Данькова Н. Як переживає пандемію ринок преси. URL: https://detector.media/rinok/article/177068/ 2020-05-12-yak-perezhyvaie-pandemiyu-rynok-presy/ (дата звернення: 26.02.2021).

6. Неперіодичні видання. URL: http://www.ukrbook.net/statistika_.html\#period (дата звернення: 26.02.2021).

7. Данькова Н. Рекламний ринок у часи пандемії: що відбувається на радіо, в диджиталі та зовнішній рекламі? URL: https://detector.media/rinok/article/176351/2020-04-14-reklamnyy-rynok-u-chasy-pandemii-shchovidbuvaietsya-na-radio-v-dydzhytali-ta-zovnishniy-reklami/ (дата звернення: 27.02.2021).

8. Рекламний ринок у часи пандемії: що відбувається на ТБ. URL: https://galtv.if.ua/news/reklamnyj-rynok-uchasy-pandemiyi-sho-vidbuvayetsya-na-tb (дата звернення: 27.02.2021).

\section{REFERENCES:}

1. How Total Media Ad Spend Will Shake Out Around the World. Available at: https://www.emarketer.com/ content/how-total-media-ad-spend-shaking-around-world?fbclid=IwAR1NOqbD8LOzFT-iuJLaHbgCpb_HBZ unt9MsHZTKLP-v3Fx3cfUPBD1_rto (accessed 26 Fabruary 2021).

2. Global Advertising Market: Industry Trends, Share, Size, Growth, Opportunity and Forecast 2021-2026. Available at: https://www.imarcgroup.com/global-advertising-market (accessed 26 Fabruary 2021).

3. Ofitsiinyi sait Vseukrainskoi reklamnoi koalitsii [Official site of the Ukrainian Advertising Coalition]. Available at: https://vrk.org.ua/ad-market/ (accessed 26 Fabruary 2021).

4. Visualizing the Evolution of Global Advertising Spend (1980-2020). Available at: https://www.visualcapitalist.com/ evolution-global-advertising-spend-1980-2020/ (accessed 28 Fabruary 2021).

5. Dankova N. (2020) Yak perezhyvaie pandemiiu rynok presy [How the press market is experiencing a pandemic]. Available at: https://detector.media/rinok/article/177068/2020-05-12-yak-perezhyvaie-pandemiyu-rynokpresy/ (accessed 26 Fabruary 2021).

6. Neperiodychni vydannia [Non-periodic publications]. Available at: http://www.ukrbook.net/statistika_html\# period (accessed 26 Fabruary 2021).

7. Dankova N. (2020) Reklamnyi rynok u chasy pandemii: shcho vidbuvaietsia na radio, v dydzhytali ta zovnishnii reklami? [The advertising market during the pandemic: what is happening on the radio, in digital and outdoor advertising?]. Available at: https://detector.media/rinok/article/176351/2020-04-14-reklamnyy-rynok-uchasy-pandemii-shcho-vidbuvaietsya-na-radio-v-dydzhytali-ta-zovnishniy-reklami/ (accessed 27 Fabruary 2021).

8. Reklamnyi rynok u chasy pandemii: shcho vidbuvaietsia na TB [The advertising market during the pandemic: what is happening on TV]. Available at: https://galtv.if.ua/news/reklamnyj-rynok-u-chasy-pandemiyi-shovidbuvayetsya-na-tb (accessed 27 Fabruary 2021). 